\title{
"I Was Not Born to Obey, but Rather to Command": The Self-Fashioning of Ṣägga Krəstos, an Ethiopian Traveler in Seventeenth-Century Europe
}

\author{
Matteo Salvadore \\ Associate Professor of History, American University of Sharjah, \\ United Arab Emirates \\ salvadorematteo@gmail.com
}

\begin{abstract}
In 1632, an Ethiopian traveler named Șägga Krəstos arrived in Cairo and introduced himself to Franciscan missionaries as the legitimate heir to the Ethiopian throne. Following conversion to Catholicism, he embarked on an epic journey throughout the Italian peninsula and France, where he was hosted and supported by the Congregation of Propaganda Fide, multiple northern Italian rulers, and the French monarchy. By cross-referencing his autobiographical statement with a vast body of archival and published sources, this article shows that Ṣägga Krəstos was an impostor, but also that, thanks to a favorable historical juncture and skilled self-fashioning, he was extensively supported by his European hosts. Șägga Krəstos's story of survival in the early modern Mediterranean dovetails with the literature on imposture, highlights the role that Africans played in the making of European expansion, and sheds further light on the condition of elite Africans in early modern Europe.
\end{abstract}

\section{Keywords}

Ethiopia - elite Africans - Ethiopian-European relations - Catholic missions imposture

\section{Introduction}

On the morning of Wednesday, March 10, 1632, an African youth knocked at the door of Cairo's Venetian consulate, asking to be treated by its resident 
physician: he had drunk "date wine" the night before and while sleeping had "felt blood coming out of his ear." The young man introduced himself as Șägga Krəstos, claimed to be the son of the slain Ethiopian Emperor Ya'əqob (1597-1603; 1605-1607), and told of his escape through the Nile Valley after the ruling Catholic Emperor Susənyos (1607-1632) had killed his father. ${ }^{2}$ The story intrigued Paolo da Lodi, who had been the consulate's chaplain as well as the prefect of the Franciscan mission in Egypt since 1630. As such, he was aware of the religious and political turmoil that the Jesuit mission had been causing in Ethiopia, and of their mission's uncertain future. Father Paolo saw the young Ethiopian as a valuable asset for an alternative missionary endeavor in Ethiopia, and informed his superior at the Congregation of Propaganda Fide in Rome. In the ensuing weeks, Ṣagga Krəstos visited Jerusalem, converted to Catholicism, then traveled to Rome, where Propaganda Fide vetted him in anticipation of his return to Ethiopia at the helm of a Franciscan mission. Instead, he would spend the rest of his life in Europe, as a guest of multiple courts, until his death in 1638 at Cardinal Richelieu's mansion in Ruel.

This article maps the trajectory and implications of Șägga Krəstos's rocambolesque journey - probably the most extensively documented experience of an African traveler in early modern Europe. I argue, as have previous scholars, that Şägga Krəstos was an impostor, but I propose a revisionist interpretation of his experience that contradicts both posthumous racist detractors and modern scholars who dismissed him as a mere curiosity or a figment of European imagination. ${ }^{3}$ Sägga Krəstos skillfully impersonated the role of the Ethiopian heir and obtained the support of many European interlocutors. He was a capable agent who capitalized on Europe's expansionist zeitgeist through cunning self-fashioning, which - as Stephen Greenblatt famously argued - "occurs at the point of encounter between an authority and an alien." ${ }^{4}$ Once in the company of Latin Christians, Șägga Krəstos mapped the complex religious and political landscape in which his interlocutors were operating, identified multiple authorities, the threats and opportunities they offered, and skillfully positioned himself to improve his lot.

1 Pietro Verniero di Montepeloso, Croniche ovvero Annali di Terra Santa del P. Pietro Verniero di Montepeloso, Tomo II, ed. Girolamo Golubovich (Florence, 1930) [henceforth Verniero], 283.

2 Dates in parenthesis correspond to birth and death, except for heads of state, in which case dates delimit time in office.

3 Giovanni Maria Acquaviva, Il principe Zaga Christos (Rome, 1935); Enrico Cerulli, Etiopi in Palestina, 2 vols. (Rome, 1943), 2:106-119; Christopher L. Miller, Blank Darkness: Africanist Discourse in French (Chicago, 1985), 35-39, 217-219.

4 Stephen Greenblatt, Renaissance Self-Fashioning from More to Shakespeare (Chicago, 1980), 9. 
Șägga Krəstos's experience dovetails with the literature on early modern imposture, particularly Miriam Eliav-Feldon's contention that the era's "selfappointed ambassadors could still play on the fears and the hopes which had initially motivated the search for new lands: a desperate need for precious metals, and luxury goods, a quest for allies against Muslim powers, and eschatological visions of establishing a Christian world empire." When non-Europeans "arrived appropriately dressed for the part, offering alliances and promoting riches and secret knowledge, they were never dismissed out of hand, no matter how far-fetched their claims, but treated with cautious respect." ${ }^{5}$ In the age of European expansion, anxiously competing secular and ordained elites, desirous of finding overseas allies who could foster their visions of empire and proselytization, welcomed exotic visitors and strove to co-opt them in their profane and sacred schemes. This had been particularly the case for Ethiopians in early modern Europe.

By the time Șägga Krəstos met Father Paolo, Ethiopian-European relations had been unfolding for more than two centuries. In the early fifteenth century, Ethiopian pilgrims and ambassadors began appearing at shrines and courts across Latin Christendom, attracting the curiosity of rulers, scholars, and pontiffs alike. ${ }^{6}$ Much of the interest they generated was predicated on their association with the European myth of Prester John: the belief that somewhere beyond the near East was a powerful Christian king who could be co-opted in the struggle against the Muslim world. Throughout the Middle Ages, European cartographers pinned the priest-king to disparate locales in a mostly unknown Asian continent, but once Ethiopians began appearing at multiple European shrines and courts learned Europeans concluded that Prester John was the ruler of the Christian Kingdom of Ethiopia. ${ }^{7}$

5 Miriam Eliav-Feldon, Renaissance Impostors and Proofs of Identity (London, 2012), 101. On imposture: Natalie Zemon Davis, Remaking Impostors: From Martin Guerre to Sommersby (Egham, 1997); Valentin Groebner, Who Are You? Identification, Dissimulation, Surveillance in the Middle Ages (New York, 2007).

6 On early Ethiopia-Europe relations: Matteo Salvadore, "The Ethiopian Age of Exploration: Prester John's Discovery of Europe, 1306-1458," The Journal of World History 21, no. 4 (2010): 593-627; Samantha Kelly, "Ewosțateans at the Council of Florence (1441): Diplomatic Implications between Ethiopia, Europe, Jerusalem and Cairo," Afriques. Débats, Méthodes et Terrains d'histoire (June 29, 2016): https://journals.openedition.org/afriques/1858. Samantha Kelly, "Medieval Ethiopian Diasporas." A Companion to Medieval Ethiopia and Eritrea, January 8, 2020, 425-453.

7 On Prester John: Charles Fraser Beckingham and Bernard Hamilton, eds., Prester John, the Mongols, and the Ten Lost Tribes (Aldershot, 1996); Manuel Joao Ramos, Essays in Christian Mythology (New York, 20o6). 
In spite of a reciprocal interest, Ethiopian-European connections developed slowly until 1520 , when a Portuguese embassy reached the Ethiopian court. ${ }^{8}$ Luso-Ethiopian relations initially flourished and were even instrumental to the survival of Ethiopian independence, threated by the neighboring Kingdom of Adal. Before long, however, counter-Reformation Catholics in Lisbon and Rome came to see Ethiopian Christianity as an unacceptable heresy tainted by Judaic practices, and in 1550, Ignatius of Loyola articulated a missionary plan to bring the kingdom into the Catholic fold. ${ }^{9}$ In the 155 os, two small Jesuit parties, operating under the authority of the Portuguese Assistancy, reached Ethiopia but faced resistance and accomplished little other than providing pastoral care for a small community of Luso-Ethiopians.

The fate of the mission changed dramatically starting in 1603, when Father Pedro Páez (1564-1622) reached Emperor Zädəngəl's (1603-16o4) court with a larger party at a more favorable conjuncture. Renewed Habsburg interest in the Red Sea, a growing Jesuit network in the Indian Ocean, and political instability following the long reign of Śärșä Dəngəl $\left(1563^{-1596)}\right.$ shaped an ideal milieu for the fathers. ${ }^{10}$ They injected themselves into Ethiopian politics, championing and being championed by Ethiopian nobles who welcomed them as purveyors of political ideas who could serve their cause as well as provide access to Portuguese support. ${ }^{11}$ By the time of Emperor Susənyos's (16o7-1632) accession, the Jesuits had entrenched themselves at court despite opposition among

8 On Europeans in Ethiopia: Matteo Salvadore, The African Prester John and the Birth of Ethiopian-European Relations 1402-1555 (New York, 2016), 128-139. On the Ethiopian presence in Rome: Samantha Kelly, "Medieval Ethiopian Diasporas," A Companion to Medieval Ethiopia and Eritrea (January 8, 2020): 425-453; Osvaldo Raineri and Ilaria Delsere, Chiesa di S. Stefano dei Mori: vicende edilizie e personaggi (Vatican City, 2015); Matteo Salvadore and James De Lorenzi, "An Ethiopian Scholar in Tridentine Rome: Täsfa Șeyon and the Birth of Orientalism," Itinerario 45, no. 1 (2021). Sam Kennerly, "Ethiopian Christians in Rome, c.1400-c.17oo," in A Companion to Religious Minorities in Early Modern Rome, eds. Emily Michelson and Matthew Coneys (Leiden, 2020), forthcoming.

9 On the evolution of Rome's stance towards Ethiopian Christianity and the making of the Jesuit mission: Salvadore and De Lorenzi, "An Ethiopian Scholar in Tridentine Rome"; Matteo Salvadore, "African Cosmopolitanism in the Early Modern Mediterranean: The Diasporic Life of Yohannes, the Ethiopian Pilgrim Who Became a Counter-Reformation Bishop," The Journal of African History 58, no. 1 (2017): 61-83; Matteo Salvadore, "Gaining the Heart of Prester John: Loyola's Blueprint for Ethiopia in Three Key Documents," World History Connected 10, no. 3 (2013), http://worldhistoryconnected.press.illinois.edu/10.3/ forum_salvadore.html.

10 Andreu Martínez d'Alós-Moner, Envoys of a Human God: The Jesuit Mission to Christian Ethiopia, 1557-1632 (Leiden, 2015), 98.

11 On the Jesuits and court politics: Leonardo Cohen, The Missionary Strategies of the Jesuits in Ethiopia (1555-1632) (Wiesbaden, 2009), 28-49. 
court clerics and the nobility: in the ensuing years, traditionalists and Catholics confronted each other; the latter prevailed. In 1621, Emperor Susənyos made a public profession of Catholic faith; in 1624, he welcomed the Jesuit Afonso Mendes as the kingdom's supreme religious authority; and in 1626, he pledged obedience to Rome. By the mid-162os, the Jesuit project was at its peak, but success was short-lived.

By the turn of the decade, anti-Catholic insurrections escalated, leading the emperor to proclaim religious freedom in summer 1632. In the fall of the same year, with Susənyos's death and the accession of his son Fasilädäs as Emperor 'Aläm Sägäd (1632-1667), the Jesuit mission unraveled.12 While news traveled slowly out of Ethiopia, and Rome would learn of Susənyos's death only in 1634, when Șägga Krəstos visited the Venetian consulate, Father Paolo was well aware of Jesuit difficulties. He recognized the young Ethiopian's potential value for a future alternative mission, and strove to co-opt him at the behest of Propaganda Fide. Hence Șägga Krəstos became involved in one of Rome's many attempts to proselytize in Ethiopia. Through the story of Șägga Krəstos, this article offers unique vistas on complex intra-Catholic dynamics and on the modus operandi of the newly established Propaganda Fide.

The article also contributes to the historiography on Africans in early modern Europe. ${ }^{13}$ While a modern notion of race began to emerge only during the scientific revolution of the eighteenth century, the association between immutable intellectual and psychological traits and descent became increasingly common with the emergence of the Atlantic slave trade and European exploration. ${ }^{14}$ During the sixteenth and seventeenth centuries, embryonic ideas of race became increasingly central to the discourse on otherness. However, despite growing discrimination for free and enslaved Africans in

12 On the Jesuit mission in Ethiopia: Martínez d'Alós-Moner, Envoys of a Human God; Cohen, The Missionary Strategies of the Jesuits in Ethiopia (1555-1632); Wendy Laura Belcher, ed., The Jesuits in Ethiopia (1609-1641): Latin Letters in Translation, trans. Jessica Wright and Leon Grek (Wiesbaden, 2017); Hervé Pennec, Des jésuites au royaume du prêtre Jean, (Éthiopie). Stratégies, rencontres et tentatives d'implantation, 1495-1633 (Paris, 2003); Matteo Salvadore, "The Jesuit Mission to Ethiopia (1555-1634) and the Death of Prester John," in World-Building and the Early Modern Imagination, ed. Allison B. Kavey (New York, 2010), 141-172.

13 For entry points in the fast-growing literature on the African presence in early modern Europe:Joaneath A. Spicer et al., eds., Revealing the African Presence in Renaissance Europe (Baltimore, 2012); Thomas Foster Earle and Kate Lowe, eds., Black Africans in Renaissance Europe (Cambridge, 2005).

14 See Cornel West, "A Genealogy of Modern Racism," in Prophesy Deliverance! An AfroAmerican Revolutionary Christianity (Louisville, 2002); George M. Fredrickson, Racism: A Short History (Princeton, 2002). 
Europe, some elite Africans still had room to maneuver. ${ }^{15}$ As Kate Lowe put it, "occasionally black Africans, by conforming to Renaissance norms of dress and behavior ... may have been able to neutralize these stereotypes and both project themselves, and be accepted, as 'honorary' Europeans, who just happened to have a black skin."16 A still-blurred color line allowed a resourceful visitor like Ṣagga Krostos to negotiate his way into European courts and befriend the learned and the powerful: his status and claimed faith proved more consequential than his African origin. His experience can hardly be reconciled with the view that "to the majority of Europeans, the defining feature of Africans was their skin colour, and nothing else - whether area of origin, religion, or previous occupation - mattered, and consequently nothing else was recorded."17 Instead, Șägga Krəstos's posthumous representation in European literature dovetails with the rapid deterioration of the discourse on Africans in late seventeenth-century France.

This article first examines Ṣägga Krəstos's dealings with the Franciscans in Cairo and Jerusalem. Second, it sketches his itinerary through the Mediterranean and Southern Italy to Rome. Third, it discusses the scrutiny he underwent at the hand of Propaganda Fide in the context of the international and intra-ecclesiastical rivalries of the day. Fourth, it reviews his journey through northern Italy and his sojourn in Paris. The conclusion speculates on his possible identity and discusses his discursive legacy and its bearing on modern historiography.

\section{"A Truly Royal Intellect"}

On March 19, 1632, within days of his first encounter with Șägga Krəstos, Father Paolo sent word to Rome of "a certain Abyssinian [who had] ... claimed to be son of the king of Abes [Habeš, i.e., Ethiopia] but as he tricked many others, so he did with me because I did not have the language [skills] to discuss what I wanted."18 What led Father Paolo to denounce the young Ethiopian as an impostor and disavow a previous letter he had written to support him?

\footnotetext{
15 Black slaves fetched lower prices in Renaissance Italy: Steven Epstein, Speaking of Slavery: Color, Ethnicity, and Human Bondage in Italy (Ithaca, 2001).

16 Kate J.P. Lowe, "The Stereotyping of Black Africans in Renaissance Europe," in Earle and Lowe, Black Africans in Renaissance Europe, 17-47.

17 Earle and Lowe, Black Africans in Renaissance Europe, 6.

18 Paolo da Lodi to Francesco Ingoli, Cairo, 19 March 1632, Archivio di Propaganda Fide [henceforth APF], Scritture riferite nelle Congregazioni Generali [henceforth socG] 149, 261r.
} 
Shortly after Șägga Krəstos had left Cairo with Father Paolo's endorsement, the Capuchin Gilles de Loches had told him that three Ethiopian pilgrims had called Șägga Krəstos "a great rogue and a liar" and cautioned him against "the guy who pretended to be the son of Prester John of Ethiopia."19 An ostensibly persuaded Father Paolo alerted both Rome and Jerusalem accordingly, recommending to ignore his previous missives, but he must have remained unconvinced. ${ }^{20}$ After reaching Jerusalem to take his new post as Guardian of the Holy Land and spending more time with Șägga Krəstos, he reconsidered again.

The "Illustrissimo Atanasio Abissino," Father Paolo related in a new letter, had been "much approved by our friars in Jerusalem and Nazareth and judged a humble youth, godly and with a royal soul" in spite of what "envious individuals" had told him in Cairo. In Jerusalem, Șägga Krəstos had greatly impressed him: especially when, on "the day of St. Peter [he] made solemn profession of the Catholic Roman Faith with great spirit."21 The conversion was a watershed moment. If self-fashioning "involves submission to an absolute power or authority" and is "achieved in relation to something perceived as alien, strange, and hostile," by converting, Ṣägga Krəstos began effacing his alterity, repositioning himself under Roman authority, and adding religious credentials to his claimed royal pedigree. ${ }^{22}$

The step Ṣägga Krəstos took is reminiscent of similar decisions in the early history of Portuguese expansion in Africa. In 1488, King Joao II received Jele, the bumi of Jolof with full honors, recognized him as a vassal, and saw him baptized. ${ }^{23}$ In the same decade, the Portuguese lavishly hosted Kongolese noblemen in Lisbon and negotiated an alliance with the equatorial kingdom. The Kongolese royals converted, and one of their sons, Henrique, studied in Rome and was eventually elevated to bishop. ${ }^{24}$ In these cases, blackness appears to have been secondary to status and religious affiliation: elite Africans could expect to be treated as such, especially those who through conversion

19 This is reported in Verniero, 284, as well as in a later report that appears to have been written by the Capuchin, presumably at Ingoli's behest: anonymous document, 1633, Biblioteca Apostolica Vaticana [henceforth BAV], Barb. lat. 46o5, 9ov.

20 On this occasion, Paolo Da Lodi also wrote to PF, for the second time, to disavow the first letter: anonymous document, 1633, BAV, Barb. lat. 4605, 91v.

21 Paolo Da Lodi to Francesco Ingoli, Jerusalem, 20 July 1632, APF, SOCG 103, $158 \mathrm{v}$.

22 Greenblatt, Renaissance Self-Fashioning, 9.

23 Ivana Elbl, "Cross-Cultural Trade and Diplomacy: Portuguese Relations with West Africa, 1441-1521," Journal of World History 3, no. 2 (1992): 198.

24 David Northrup, Africa's Discovery of Europe: 1450-1850 (New York, 2002), 37-38; John K. Thornton, "The Development of an African Catholic Church in the Kingdom of Kongo, 1491-1750," Journal of African History (1984): 84. 
turned themselves into instruments of Catholic proselyting. Tellingly, a stunning cycle of frescos completed in 1617 in the newly built papal residence of the Quirinale Palace, celebrated Rome's global reach through the representation of exotic personalities who either converted to Catholicism, visited Rome, or both. Among them are the Kongolese ambassador Anthony Manuel Ne Vunda, who died in Rome and was buried in Santa Maria Maggiore, and the Catholic Ethiopian stalwart Ras Śəəəlä Krəstos, Emperor Susənyos's half-brother and paladin of the Jesuit cause. ${ }^{25}$

In this context of militant missionarism, by running into Father Paolo, Ṣägga Krəstos had struck gold: the Franciscans and Propaganda Fide were eager to find an alternative to the faltering Jesuit mission. His doubts dissipated, Father Paolo arranged for Șägga Krəstos's journey to Rome on a Venetian vessel ${ }^{26}$ and wrote a lettera patente that presented him as "Abdel Messiah or Athanasio," son of the late Ethiopian emperor, and as a "truly royal intellect" who "was on fire for the Catholic faith." Father Paolo was sold: of all the documents that would be written on Șägga Krəstos's behalf during his journey, the lettera patente would remain the most ringing endorsement he would ever receive. ${ }^{27}$

\section{On to Rome}

Having spent the summer between Jerusalem and Nazareth, in September 1632 Șägga Krəstos sailed out of Haifa, called at multiple Venetian outposts, and landed in Otranto in Apulia. ${ }^{28}$ His transit through the Habsburg held Kingdom of Naples boded well. In Lecce, Șägga Krəstos was granted "many honors as much from the archbishop as from the viceroy who arranged for his journey to Naples, which he undertook on the back of a horse of great value given to him by the Prince of Avetrana [Giovanni Antonio III Abrizzi]."29 In Naples, where he stayed throughout December, the Hapsburg Viceroy Manuel de Acevedo y Zúñiga entertained him at court, supported his stay in the city, and provided

25 Cristelle Baskins, "Locating the Chaldean Embassy to Pope Paul V in the Sala Regia of the Palazzo Quirinale in Rome," Memoirs of the American Academy in Rome 59 (2014); Martínez d'Alós-Moner, Envoys of a Human God.

26 Paolo Da Lodi to unknown Venetian official, Jerusalem, 3 September 1632, APF, socG 103, 16rir.

27 Paolo Da Lodi, Jerusalem, 4 September 1632, APF, SOCG 211, 154-155.

28 Verniero, 292-293; Theophraste Renaudot, Vingt-Deuxiesme Tome du Mercure françois (Paris, 1646), 26o.

29 Estienne Richer, ed., Le Mercure françois, vol. 19 (Paris, 1636), 692. 
carriage, military escort, and 100 scudi for his journey. ${ }^{30}$ Nevertheless, the resident nuncio wasted no time sending word to Rome that Șägga Krəstos had no credentials - a lack of proof that would haunt him throughout his sojourn in Rome and beyond. ${ }^{31}$

Father Paolo's lettera patente had given him the keys to the heart of Europe, but for the self-styled heir, the vetting process had barely begun, and shortly after arriving in Rome in early 1633 he began facing resistance.

Malevolent individuals ... did not want the youth to be received in the way he expected to be [i.e., as a Prince]. They argued that he had come to Rome to mock and trick the Church, and they put forward many [similar] examples from the past. Others said that we, friar minors [Franciscans], were seeking power through this pretext, but that we were confused. Others argued that we were conniving. [...] [And] that we friar minors are the one [responsible for] putting the Church in these difficult circumstances. $^{32}$

What transpires from the passage is not only a general sense of distrust surrounding Ṣägga Krəstos but also enmity towards his sponsors. The "malevolent individuals" can be confidently identified as Jesuits and their Portuguese patrons, who were not only struggling to save the mission in Ethiopia from traditionalist resurgence but also occupied with preserving their overseas prerogatives from the centralizing aspirations of the Congregation of Propaganda Fide.

Shortly after its creation in 1622, the congregation began wrestling with the Portuguese monarchy to recover a variety of ecclesiastical privileges that Portuguese royals had secured for their overseas territories in the heyday of exploration - the set of institutions and practices known as the padroado. It also worked to limit the excessive autonomy enjoyed by religious orders, in particular the Jesuits, in partibus infidelium. Given that the mission in Ethiopia epitomized both the Portuguese and Jesuit prerogatives that Propaganda Fide was looking to curtail, Șägga Krəstos's presence in Rome could have hardly gone unnoticed in Portuguese-Jesuit circles, and his arrival "was brought to

30 Niccolò Enriquez de Herrera to Francesco Barberini, Naples, 28 December 1632, BAV, Barb. lat. 7496, 101; Verniero, 293; Niccolò Enriquez de Herrera to Francesco Barberini, Naples, 1 January 1633, BAV, Barb. lat. 7497, 1.

31 Niccolò Enriquez de Herrera to Francesco Barberini, Naples, 1 January 1633, BAV, Barb. lat. 7497,1.Onthenuncio:MassimoBray, "Herrera,Niccolò,"inDizionarioBiograficodegliItaliani, 61 (2004), http://www.treccani.it/enciclopedia/niccolo-herrera_(Dizionario-Biografico)/.

Verniero, 293. 
the attention of the Portuguese Resident, a Jesuit father, and when two Jesuits went to visit him, they had a bad encounter."33 The Portuguese Jesuits were most likely the instigators of the Vicar of Rome Cardinal Mario (or Marzio) Ginetti's decision to "order [...] the said youth not to leave that convent to walk around Rome, or to visit the church, but that instead he leave Rome as soon as possible: and he wanted to jail that father [the Franciscan Bartolomeo da Pettorano] for having taken that youth there." 34

Șägga Krəstos was in the midst of a tug-of-war between religious orders, the papacy, and the padroado. ${ }^{35}$ His detractors wanted him gone, or at least secluded in the Franciscan convent, San Pietro in Montorio in Trastevere, where he was being hosted. ${ }^{36}$ Luckily, he could count on the protection of Francesco Ingoli (1578-1649), the congregation's first secretary and the mastermind of its growth into a global institution. ${ }^{37}$ Ingoli reported Ṣägga Krəstos's arrival to his superior, Cardinal Antonio Barberini the younger (16o7-1671), the congregation's prefect, and to Cardinal Francesco Barberini (1597-1679), Vice-Chancellor and Grand Inquisitor, both of whom were the powerful cardinal nephews of Maffeo Barberini, i.e., Pope Urban VIII (1623-1644). Thanks to Father Paolo's endorsement, Șägga Krəstos was only twice removed from the pope himself and had become a household name in one of the most powerful European families of the time.

Ingoli related to Cardinal Francesco's secretary that he had "learned from those who met him, that he has the appearance and manners of a royal,"38 a characterization of the young Ethiopian that in the ensuing years would be echoed across Italy and France. Yet, despite his eagerness to support Șägga Krəstos and his Franciscan sponsors, Ingoli needed proof: not only

\footnotetext{
33 Verniero, 293.

34 Father Bartolomeo da Pettorano had escorted Șägga Krəstos from Jerusalem to Rome: Verniero, 293.

35 Dauril Alden, The Making of an Enterprise: The Society of Jesus in Portugal, Its Empire, and Beyond, 1540-1750 (Stanford, 1996), 13. Giovanni Pizzorusso, "Il padroado regio portoghese nella dimensione 'globale' della Chiesa romana," in Gli archivi della Santa Sede come fonte per la storia del Portogallo in età moderna, eds. Giovanni Pizzorusso, Gaetano Platania, and Matteo Sanfilippo (Viterbo, 2012), 177-221; Donald F. Lach and Edwin J. Van Kley, Asia in the Making of Europe, vol. 3, bk. 1 (Chicago, 1993), 130-144 and 222-226.

36 Ṣägga Krəstos initially stayed at San Francesco a Ripa, also a Franciscan convent in Trastevere, but was relocated within weeks of his arrival. Verniero, 293.

37 Josef Metzler, “Francesco Ingoli, DerErsteSekretär der Kongregation(1578-1649)," in Sacrae Congregationis de Propaganda Fide Memoria Rerum, ed. Josef Metzler (Freiburg, 1971), 197-214; Giovanni Pizzorusso, "Ingoli, Francesco", Dizionario biografico degli Italiani, 62 (2004) at http://www.treccani.it/enciclopedia/francesco-ingoli_(Dizionario-Biografico)/.

38 Francesco Ingoli to Pietro Benessa, Rome, 10 January 1633, APF, socG 103, 155r.
} 
because of his role as a high-ranking office holder in the Church but also as a scientist and professor of law. Ingoli was an accomplished Ptolemaic astronomer and one the chief critics of Galileo Galilei, whose sojourn in Rome - for the famous trial - coincided with Șägga Krəstos's. ${ }^{39}$ In the ensuing months, Ingoli would methodically gather and parse any evidence he could find to ascertain his guest's claimed identity. Nowhere else would Șägga Krəstos be subjected to a more thorough vetting: his words were cross-referenced with multiple testimonies and also tested against what was known about Ethiopia's dynastic politics and history - luckily for him, very little.

The centerpiece of Ingoli's inquiry was a five thousand word statement that Șägga Krəstos produced while in Rome, the first comprehensive autobiographical account by an African to be printed in Europe. ${ }^{40}$ What is in all likelihood the oldest extant version, Narratione del viaggio fatto dall'Altezza Seren(issima), del sig. Zagra Cristos figliolo dell'Imperator d'Ethiopia [Narratione] is bound in a codex of the Biblioteca Apostolica Vaticana's vast Barberini collection - an unsurprising location given that the results of Ingoli's investigation were sent to Cardinal Antonio Barberini (16o7-1671). ${ }^{41}$

The statement survives in multiple manuscript and printed versions that vary to different degrees and also include additions pertaining to Ṣägga Krəstos's European journey. One of the manuscript copies appears identical to the Narratione and is held in a private collection..$^{42}$ Another, the most dissimilar, can be found in a letter Șägga Krəstos dispatched to one "Gualdi," i.e., Francesco Gualdo, cameriere segreto [secret chamberlain] of Pope Urban VIII, famous across Europe for his Wunderkammer. ${ }^{43}$ Șägga Krəstos explains that he included in the letter "a brief narrative of the genealogy of my imperial ancestry, [to be added to] [...] other memorable and illustrious things of your museum," to

39 William R. Shea and Mariano Artigas, Galileo in Rome: The Rise and Fall of a Troublesome Genius (Oxford, 2003), 86-122.

40 In the sixteenth century, two Ethiopians produced brief autobiographical statements in print: $a b b a$ Tomas Wäldä Samu'el inserted an autobiographical sentence in Johannes Potken, Psalterium David et cantica aliqua in lingua Chaldea (Rome, 1513); and abba Täsfa Șəyon included references about himself in his Petrus Ethyops [Täsfa Ṣeyon], Testamentum Novum Cum Epistola Pauli Ad Hebreos (Rome, 1548).

41 Narratione del viaggio fatto dall'Altezza Seren(issima), del sig. Zagra Cristos figliolo dell'Imperator d'Ethiopia, BAv, Barb. lat. 5142, 25r-37r.

42 Narratione [...] was auctioned by Bonhams Fine Art Auctioneers \& Valuers in 2008. Its foliation (420-427), corresponds to the copy described in Stuart Munro-Hay, Ethiopia Unveiled: Interaction between Two Worlds (Hollywood, 2006), 237-238.

43 Maria Elena Massimi, "Gualdo, Francesco," in Dizionario Biografico degli Italiani, 6o (2003), http://www.treccani.it/enciclopedia/francesco-gualdo_(Dizionario-Biografico)/. 
reciprocate Gualdo's generosity. ${ }^{44}$ The document confirms that the statement was autobiographical and that Șägga Krəstos carried his own copy, which he would share with his interlocutors throughout Europe. This could explain how one of the extant manuscripts, bound into a chronicle, was recovered at Santa Maria Seconda in Morlupo, a Franciscan convent located one day's walking distance from Rome: Sägga Krəstos is likely to have stayed there while making his way north, and allowed his hosts to copy it. ${ }^{45}$

Ṣägga Krəstos certainly shared his statement with the historian Maiolino Bisaccioni, who included it in his 1634 study of the unfolding Thirty Years' War, thereby producing the first printed version. Bisaccioni met Ṣägga Krəstos in Venice in the first half of 1634 and, like Father Paolo, was charmed:

I saw the youth, 19 or 20 years old, of a color between black and olivecolor [olivastro], of much beautiful aspect, with sparse facial hair [di prima lanugine ], with very black and curly hair, and of medium height; I found him to be of good wit, well versed in the holy scriptures, very devout, affable, majestic, and melancholic because of his accidents. ${ }^{46}$

A few months later, a new version was printed in Paris in a pamphlet form, shorty after Șägga Krəstos's arrival in the city, and more or less revised versions would follow posthumously. ${ }^{47}$

44 Șägga Krəstos to Francesco Gualdo, San Pietro in Montorio (Rome), 1 November 1633, Special Collections, University of Amsterdam, ET 124, 1-22, 1r.

45 "Libraria del Convento di Morlupo," Francesco Maria da Collamato, Vicende del Tempo, Tomo 2, 1672, Archivio di San Francesco a Ripa, Rome.

46 Maiolino Bisaccioni, Seconda continuatione del Commentario delle guerre successe in Alemagna, e fatti più notabili dell'Europa dall'assedio di Costanza 1633 alla Dieta di Francoforte 1634 (Venice, 1634), 57.

47 Jean Giffre de Rechac, Les Estranges evenemens dv Voyage de Son Altesse, le Serenissime Prince Zaga-Christ d'Éthiopie, du grand empire des Abyssins (Paris, 1635). Giffre de Rechac is the pen name of the Franciscan Jean de Sainte-Marie, who befriended Șägga Krəstos in Paris and helped him publish his story. Father Pietro Verniero da Montepeloso, who was in Jerusalem at the time of Șägga Krəstos's visit, included a copy of the statement, along with his own recollection and impressions in the chronicle he wrote in the 163 os and 1640s: Verniero, 275-301; Padre Verniero di Montepeloso, Croniche o Annali di Terra Santa, Biblioteca Pontificia Università Antonianum, Ms. 61, 37-53. A similar version can be found in another chronicle mostly lifted from Verniero's: Juan de Calahorra, Chronica de la prouincia de Syria y Tierra Santa de Gerusalen (Madrid, 1684). A much-revised version, in part the result of personal recollection and in part lifted from Rechac's, was included by the pilgrim Eugène Roger, who befriended Ṣägga Krəstos in the Holy Land: Eugène Roger, La Terre Sainte (Paris, 1646); Pierre d'Avity, Le monde, ou la description générale de ses quatre parties (Paris, 166o), 558-562; Francisco Jesús María de San Juan del Puerto, Patrimonio seraphico de Tierra Santa (Madrid, 1724), 375-387. 
The Narratione begins with a precise genealogical claim in line with what Șägga Krəstos had told Father Paolo:

The father of Sagracristos was baptized Clarso and his father was Emperor Malach Sagad [Mäläk Sägäd], son of Adema Sagad [Admas Sägäd], and this was son of Unach Sagad [Wänag Sägäd], likewise emperors. Malach Sagad [Mäläk Sägäd] ruled for thirty years and before his death he gathered all the Princes and Kings of the City with thirty priests, some Bishops and other Patriarchs and he had them vowed fealty by swearing on the book of the Gospels, that after his death, they would have appointed as their emperor no one but Clarso his son, and they would have called him Giacob [Ya'əqob]. ${ }^{48}$

This coherent genealogy introduces a detailed account of the rise and eventual fall of Emperor Ya'əqob that shows Ṣagga Krəstos's familiarity with Ethiopia's recent dynastic history. It is impressively consistent with the multiple versions of the so-called Short Chronicles, a dynastic history compiled in the seventeenth century from pre-existing sources, and also with the much more extensive chronicle of Susənyos. ${ }^{49}$

The Narratione relates the stormy years following Emperor Śärșä Dəngəl's [Mäläk Sägäd] long reign: the elevation of a six-year-old Ya'əqob as Emperor Mälkə’a Sägäd after his natural father's death; Ras Zäśəllase's revolt against Ya'əqob; Ya'əqob's exile after a five-year reign (1597-1603), and the crowning of Zädəngəl as Emperor Aṣnaf Sägäd II (1603-1604). It continues with Zädəngəl's death at the hands of Zäśallase, the restoration of Ya'əqob (1605-16o7), and his struggle with the contender Susənyos. It also discusses the latter's low birth, his Oromo upbringing, his flight among the Oromo after his initial defeat by Ya'əqob, and his eventual victory and elevation as Səltan Sägäd I. ${ }^{50}$ Following is

48 Ṣägga Krəstos correctly traced Ya`əqob’s genealogy by identifying him as the son of Śärșä Dəngəl (1550-1597, crowned Mäläk Sägäd in 1563), the grandson of Minas (1526/9-1563, crowned Admas Sägäd in 1559), and the great-grandson of Ləbnä Dəngəl (1496/7-154O crowned Wänag Sägäd in 1508): Narratione, 25 r.

49 On the authorship of the Short Chronicles: James De Lorenzi, Guardians of the Tradition: Historical Writing in Ethiopia and Eritrea (Rochester, 2015), 22-29; Manfred Kropp, "A Hypothesis Concerning an Author or Compiler of the 'Short Chronicle' of the Ethiopian Kings," in Proceedings of the 6th International Conference of Ethiopian Studies, Tel Aviv (Rotterdam, 1980), 359-372; Concetta Foti, "La cronaca abbreviata dei re d'Abissinia in un manoscritto di Dabra Berhan di Gondar," Rassegna di studi etiopici 1, (1941): 87-123; A. Caquot, "Les “Chroniques Abrégées" d'Éthiopie," Annales d'Ethiopie 2 (1957): 187-192.

$5^{\circ}$ Compare Barb. lat. 5142, 25r-27v with the Short Chronicle: Francesco Béguinot, La cronaca abbreviata d'Abissinia (Rome, 1901), 41-42. Jules Perruchon, "Notes Pour l'histoire 
an account of Şägga Krəstos's escape from Ethiopia, his sojourn in the Sultanate of Sinnār, ordeal through the Nile Valley, sojourn in Cairo and Jerusalem, and arrival in Rome. For the events predating Ṣagga Krəstos's arrival in Cairo, the Narratione, along with the testimony of one of Sägga Krəstos's acquaintances, is the only available source. ${ }^{51}$

The Narratione is an impressive document, but despite the accurate telling of dynastic Ethiopian history, it is ultimately self-defeating: when crossreferenced against the historical record, its chronology appears abundantly off. Sägga Krəstos greatly inflated the confrontation between Susənyos and Ya'əqob, claiming that the former defeated the latter "after reigning twentythree years" or five years earlier in 1627 , whereas the chronicles and additional Ethiopian and European sources confirm that Ya'aqob reigned only from 1597 to 1603 and then again from 1605 to 1607 , when he was killed in battle. ${ }^{52}$ Șägga Krəstos also claimed that his mother Nazarena - not mentioned in any

d'Ethiopie: Règne de Yaqob et Za-Dengel 1597-16o7," Revue Sémitique 4 (1896): 355-363; Ignazio Guidi, "Di due frammenti relativi alla storia di Abissinia," Rendiconti della Reale Accademia dei Lincei, Serie Quinta, 2 (1893): 579-605, 593; Ignazio Guidi, "Due nuovi manoscritti della «Cronaca Abbreviata » d'Abissinia," Rendiconti della Reale Accademia dei Lincei, Serie Sesta, 2 (1926): 357-421; Jules Perruchon, "Notes Pour l'histoire d'Ethiopie : Regne de Minas Ou Admas-Sagad (1559-1563)," Revue Sémitique 4 (1896): 87-9o; Caro Conti Rossini, Carlo, "Due squarci inediti di cronica etiopica," Rendiconti della Reale Accademia dei Lincei, Serie Quinta, 2 (1893): 804-818, 814; F.M. Esteves Pereira ed., Chronica de Susenyos, Rei de Ethiopia. Vol. 2 (Lisboa, 19oo); Pedro Páez, Pedro Páez's History of Ethiopia, eds. Isabel Boavida, Hervé Pennec, and Manuel João Ramos, trans. Christopher J. Tribe (Burlington, 2011), 206-225.

$5^{1}$ Marco Lombardo, a Venetian renegade who was in Nazareth at the same time as Șägga Krəstos, claimed to have met Șägga Krəstos in Ethiopia and confirmed his royal claim. Lombardo's fantastic claims about himself and Șägga Krəstos (Roger, La Terre Sainte, 410-411; Paolo Da Lodi, Jerusalem, 4 September 1632, APF, SOCG 211, 154-155) are tellingly absent from the formal statement he made at the Venetian Inquisition during his reconciliation hearing: Marco Lombardo, 8 November 1632, Archivio di Stato di Venezia, Santo Uffizio, Processi, b. 88. On Lombardo: E. Natalie Rothman, Brokering Empire: Trans-Imperial Subjects between Venice and Istanbul (Ithaca, 2012), 106.

$52 \quad$ Narratione, 27r. Emperor Susənyos told Pope Paul v that he had recovered the throne in 1607: Susənyos to Paul v, 20 June 16o9, in Osvaldo Raineri, Lettere tra i pontefici romani e i principi etiopici, sec. XII-XX (Vatican City, 2005), 151. Additionally, Susənyos issued a declaration of faith that was distributed throughout his kingdom in 1624 that refers to Ya'əqob's first and second tenure and death consistently with the Short Chronicles: Affonso Mendes and Camillo Beccari, eds., Expeditionis Aethiopicae, vol. 9: Rerum Aethiopicarum Scriptores Occidentales Inediti a Saeculo XVI Ad XIX (Rome, 1908), 113-117. The Jesuit Pedro Páez (1562-1622) stated that when he arrived in Ethiopia in May 1603, Ya'əqob was emperor, that he was dethroned in September 1603, regained the throne in October 1605, and was finally killed in 1607: Páez, Pedro Páez's History of Ethiopia, 75; Foti, "La cronaca abbreviata dei re d'Abissinia," 111. Finally, the Short Chronicles relate that 
other source - had borne his father Ya'əqob multiple children and that his father's throne name had been "Clarso."53 Instead, Ya'əqob is the accepted birth name of Mälkə’a Sägäd, who died at age twenty and is not known to have married or fathered any heir. It is possible that he did, and that they were omitted from the chronicles for political reasons, but the chronology leaves hardly any doubt that Şagga Krəstos was an impostor: he claimed to be someone he was not and who had, most likely, never existed. ${ }^{54}$

Why would Șägga Krəstos be so accurate and detailed in his narrative but so outlandish with the chronology? Only by expanding Emperor Ya'əqob's lifespan and tenure by two decades could Ṣagga Krəstos justify his claim. Having told Father Paolo that he was sixteen years old, i.e., born in $1616,{ }^{55}$ he needed Ya'əqob to have survived well past 1607 , until shortly before his escape from Ethiopia in the late 1620 . The chronology of the Narratione would have been enough to reject Șägga Krəstos's claim, but his hosts had little to go on other than his word. For Ingoli, skepticism was in order: accepting the claim was tantamount to making Sägga Krəstos the centerpiece of a highly contested missionary effort and exposing Propaganda Fide and the entire Church to much embarrassment if he was proven to be an impostor.

As a responsible administrator and a man of science, Ingoli needed evidence. He not only solicited testimonies but also:

wanted Father Paolo da Lodi ... to send [to Rome] three or four servants [who had been in Șägga Krəstos's service] or affidavits by Catholic consuls and merchants living in Cairo, or by Greeks and Armenians, which could confirm him to be who he claimed to be, and allow the pope to receive him with due honors. ${ }^{56}$

The effort was on the whole unsuccessful: none of Șägga Krəstos's companions could be found, let alone taken to Rome, and only one rather weak affidavit made it there. At Ingoli's behest, Cairo's Venetian consul interviewed one

Susənyos defeated Ya'əqob in the year 7099 of the world's creation, which corresponds to 1607 .

53 Narratione, $1 \mathrm{r}$.

54 The chronicles, repositories of Ethiopia's official history, were carefully controlled and manipulated to legitimize state power and can hardly be considered an objective source: J. McCann, "The Ethiopian Chronicles: An African Documentary Tradition," Northeast African Studies 1, no. 2 (1979): 47-61; De Lorenzi, Guardians of the Tradition, 25-36; M. Kropp, "Un cas de censure politique au XVIIe siècle: la chronique de Sarsa-Dengel," in Annales d'Ethiopie 17 (2001): 257-277.

55 Paolo Da Lodi, Jerusalem, 4 September 1632, APF, SOCG 211, 154r.

56 Verniero, 294. 
"Dilaver Aga, Abissino Turco eunuco," who was reportedly serving at Cairo's gran seraglio. The eunuch, whom Șägga Krəstos mentioned in the Narratione as one of his benefactors, confirmed that Șägga Krəstos was the "son of the emperor of Abas [Habeš]," but only on the grounds that "this is something known to everyone." 57

It is unclear whether Ingoli was also the commissioner of the notarized affidavits two Maronites, "Baptista Hannetus" and "Gabriel Rabias," wrote on Șägga Krəstos's behalf in Rome in late 1633. They claimed they were serving the Custody as interpreters when Ṣägga Krəstos arrived in Jerusalem, that they heard he was the son of the Ethiopian emperor, and that "all the Abyssinians who were then in the same place and even the highest ones kissed the hands of the young Ethiopian several times ... a ceremony that is only done for kings." ${ }^{.5}$ What can be said about these statements? They appear authentic in that the identities of one of the two Maronites and of the notaries can be confirmed, but they do not go beyond reporting impressions and hearsay that could have hardly persuaded Ingoli. ${ }^{59}$ Unsurprisingly, these two affidavits do not seem to have made much of an impression: unlike the Narratione and Dilaver Aga's affidavit, they do not appear to have been filed at Propaganda Fide.

By the early seventeenth century, authorities expected travelers to carry letters of conduct enriched with what have been called "semiotic validation codes that operated as doublings of physical presence": the issuer's insignia, seals, stamps, and detailed scribe colophons. ${ }^{60}$ About a century earlier, the Jewish impostor David Reuveni (ca.1490-1538) had conned authorities throughout Italy and Iberia, relying on impressive letters of introduction. ${ }^{61}$ But Ṣagga Krəstos could not provide any document even remotely authoritative.

57 Francesco Boni, "Fede di Zagachristo Principe d'Etiopia," 15 October 1633, Cairo, APF, SocG 104, 158r. He is probably the Dilaver Agha who became Chief Eunuch in Constantinople in 1656: Jane Hathaway, The Chief Eunuch of the Ottoman Harem (Cambridge, 2018), 284.

$5^{8}$ The two affidavits only survive in French translations in Valentin Conrart's (1603-1675) famous recueils, whose purpose and provenance are unknown. One can speculate, however, that the Italian originals were part of Șägga Krəstos's credentials portfolio and that Conrart, founder of the Académie Française, acquired them from his patron Cardinal Richelieu after Șägga Krəstos's death: Valentin Conrart "Lettres et pièces touchant Zagachrist, soy-disant prince d'Éthiopie," in Recueil de pièces historiques, Tome II (16291638), Bibliothèque nationale de France, Ms. 3447, 211v-214v.

59 On Gabriel Rabias: Peter Miller, Peiresc's Mediterranean World (Cambridge, MA, 2017), 276. The notaries mentioned in the affidavits - "Francesco Arigonus," "Octavian Nardotius," and Pietro Francesconius - are listed as Roman notaries in Romina De Vizio, Achille Francois, and Fondazione Marco Besso, Repertorio dei notari romani dal 1348 al 1927: dall'Elenco di Achille Francois (Rome, 2011), 8, 92, 100.

6o Groebner, Who Are You? 16o-191.

61 Groebner, Who Are You? 214-215. 
Ingoli, for his part, kept digging, and he was probably responsible for commissioning two short reports attached to the Narratione. The first justifies the absence, in the annual Jesuit letters, of Șägga Krəstos, and some of the events he related, on the ground that the fathers wrote "briefings for their superiors" that were far from exhaustive. The second explains away naming discrepancies in light of traditional Ethiopian naming practices, and Șägga Krəstos's adoption of different names in the Holy Land as a practical decision. Albeit indirectly supportive, like the affidavits, these reports must have meant little to the skeptical secretary. ${ }^{62}$

\section{A Young Man Full of Confidence}

Despite his efforts, Ingoli had little to go on other than Șägga Krəstos's own words and a few reported impressions, and he opted to focus on the former. He reworked the Narratione into a tabulated chronology entitled Brevissima narratione del imperatore Jacob disposta per ordine d'anni $[\text { Brevissima }]^{63}$ and organized in three columns including, respectively, calendar year, Emperor Ya'əqob's claimed corresponding age, and key events discussed in the Narratione, along with a few additions. ${ }^{64}$ In light of the historical record, the Brevissima leaves little doubt that Șägga Krəstos was an impostor, but Ingoli, seemingly oblivious to Ethiopia's dynastic chronology, could not reach the same conclusion - little did he know he was staring right at the evidence he had been looking for, produced by Ṣägga Krəstos himself.

Instead, in detailed reports, he wondered what the Church was to do, given that they did not have "a sufficient certainty of this gentleman's attributes." Should "the Apostolic See recommend him to the Christian princes to have him returned to Ethiopia?" he asked. The Church could not endorse Șägga Krəstos's

$62 \quad$ Notatione prima per concordare quello che dice SagaCristos con quello che si trova scritto nelle lettere annue d'Etiopia scritte al Reverendissimo Padre Generale de Gesuiti and Notatione s(econ)da per la variatione de nomi di SagaCristos e di suo Padre, BAV, Barb.

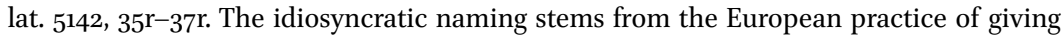
Ethiopians familiar Latin names - such as the Latin "Athanasius" - as well as sheer mishandling. Father Paolo turned "Clarso," which is how Șägga Krəstos referred to his father, into "Claudio of Arzo," probably because since the time of Gälawdewos (1540-1559), Claudio was a known Ethiopian name in Rome. Șägga Krəstos's names are discussed in Verniero, 276 .

63 Francesco Ingoli, "Brevissima narratione dell'Imperatore Jacob disposta per ordine d'anni," APF, SOCG 211, 162v-163r.

64 The spelling of names and the dating of events shows that the Narratione was Ingoli's source. 
claim because the evidence was not there, and "if he is not who he claims to be, the princes we would recommend him to could resent having been deceived." Still, supporting him "is what charity to our neighbor calls for," and, he reasoned, the future of Catholicism in Ethiopia was at stake. What would happen if "he [Șägga Krəstos] ever returned to Ethiopia, without being well treated and helped by this court and by the Catholic prince [?]." "If this gentleman is what he claims to be [and we do not help him], he could procure much damage to religion in Ethiopia, and conversely do a lot of good, if we help him" [emphasis added]. ${ }^{65}$

Ingoli was well aware that his guest could turn into an asset or a liability, depending not only on who he was but also how he was treated. He concluded that Șägga Krəstos should not be officially endorsed, but should be supported with carefully phrased letters showing "the evidence that the Holy Congregation has of the quality of said gentleman."66 One wonders whether Ingoli knew that the papacy had done the same with Reuveni, whose claims were also neither endorsed nor denied. ${ }^{67} \mathrm{~A}$ century had passed, but reserving judgment still appeared the most sensible option. Ingoli was facing a common early modern challenge: how to prove the identity of a foreign visitor coming from afar. Like Leo Africanus and David Reuveni, Șägga Krəstos was one of the "enigmatic foreigners passing through early modern European courts, whose history and credentials could not be fully verified." 68

Ingoli had to weigh options and lay out a plan. He believed Ṣägga Krəstos needed a patron state to support his return, and he carefully weighed different scenarios. It was not advisable to seek Spanish-Portuguese support, because Șägga Krəstos had antagonized the Jesuits in Rome and because the Iberians would have had no interest in destabilizing their current arrangement with the reigning Emperor Susənyos, who had killed Ya'əqob. Ingoli also excluded the Venetian option, despite the republic's extensive reach in the Red Sea, because he doubted its willingness to compromise its relations with the Ottomans, historically wary of European-Ethiopian dealings. The French option was more appealing - Șägga Krəstos could be entrusted to the French Franciscans - but "the French would create great discord in Ethiopia and war with the Portuguese; the danger is that of ruining the Catholic faith and giving Ethiopians a chance to throw out both the Spaniards and the French." ${ }^{\prime 9}$

\footnotetext{
65 Francesco Ingoli to Antonio Barberini [winter 1633], Rome, APF, SOCG 211, 158r-164r.

66 Francesco Ingoli to Antonio Barberini [winter 1633], Rome, APF, SOCG 211, 16or.

67 Eliav-Feldon, Renaissance Impostors, 68-96.

68 Eliav-Feldon, Renaissance Impostors, 74.

69 Francesco Ingoli to Antonio Barberini [winter 1633], Rome, APF, SOCG 211, 16ov.
} 
Lastly, Ingoli suggested the Duchy of Tuscany because of its special relationship with the "Emir di Saida," i.e., the Druze Emir Fakhr al-Din (1591-1635), the ambitious Ottoman governor who had been in negotiations with the Medici since 1610 and whose story had much in common with Șägga Krəstos's. The Emir had received support from both the Medici and Pope Paul v (1605-1621) for a wildly optimistic plan: liberating Jerusalem and creating an independent state across the Levant. Between 1613 and 1615 , he had absconded with his entourage in Tuscany, hosted by Duke Cosimo II de' Medici (16o9-1621) at considerable expense. ${ }^{70}$ Unlike Ṣägga Krəstos, the Emir never converted, and he was no impostor, but like Şägga Krəstos, he refashioned himself by arguing that the Druzes could accept Christian baptism and feign crusader lineage to be accepted by his interlocutors. ${ }^{71}$

Ingoli showed an advanced understanding of the geopolitics of European expansion and much consideration for Șägga Krəstos but neglected to consider one fundamental factor: Șägga Krəstos's own plans. Sometime between his stay in Cairo and arrival in Rome, after months spent in the company of lay and ordained personalities, the young Ethiopian must have realized he could capitalize on intra-European competition. In Rome he fashioned himself as the royal he claimed to be, and from his quarters in Trastevere he ventured across the city, enjoyed an eventful social life, and showed an uncanny ability to befriend powerful individuals - all in utter disregard of the vicar's intimations. Ingoli grew anxious:

This young man [Ṣagga Krəstos] full of confidence ... told me that the female French ambassador ${ }^{72}$ wanted to meet him ... and after much reasoning with her he told her his situation and the lady invited him with various promises to pass through France. This gentleman [Ṣägga Krəstos] did not give any response, because he was negotiating with the Venetian ambassador so that the Republic could take him to Ethiopia; ... [for which] he would have recognized it a benefit. But the [Venetian]

70 The Duke disbursed 2000 scudi per year and invested 30,0oo more to equip a fleet - to no avail, as the plan was never implemented: T.J. Gorton, Renaissance Emir: A Druze Warlord at the Court of the Medici (London, 2013), 115.

71 Gorton, Renaissance Emir, 54-57. Abdul-Rahim Abu-Husayn, The View from Istanbul: Lebanon and the Druze Emirate in the Ottoman Chancery Documents, 1546-17n1 (London, 2004), 18-23.

72 Șägga Krəstos entertained relations with the French ambassador Charles I de Créquy (1578-1638) and his second wife Francoise de Bonne (1576-1621); the latter appears to have encouraged him to travel to Paris: "Crequi, Charles de," in Louis Moréri, Le Grand dictionnaire historique, vol. 4 (Paris, 1759), 248; "Crequi, Charles de," in Jean-Baptiste Ladvocat, Dictionnaire historique et bibliographique portatif (Paris, 1777), 468; Roger, La Terre Sainte, 412. 
ambassador did not approve for various reasons, in particular, because here he [Ṣagga Krəstos] was not recognized as the man he was presenting himself to be; he turned his soul to avail himself to the French, unwilling to pass through the hands of the Spanish ...73

Șägga Krəstos could not be contained by either friends or foes: he was a free agent and a shrewd negotiator capable of ingratiating himself with some of the city's most powerful dwellers. He was also lucky, as he had reached Rome at a time when concerns for the future of Ethiopia were mounting.

While Șägga Krəstos was transiting through the Mediterranean the previous September, Susənyos had died shortly after abdicating in favor of Fasilädäs, crowned as Emperor 'Aläm Sägäd (also Səltan Sägäd II). Supported by the traditionalist faction, Fasilädäs did not wait long to launch a comprehensive campaign to eradicate Catholicism and expel the fathers from his kingdom. ${ }^{74}$ Although news of the succession would not reach Rome before mid-1634, ${ }^{75}$ Șägga Krəstos shrewdly depicted a disquieting scenario for Ingoli. He explained that Susənyos was old and likely to die soon; then his wife, a "very obstinate schismatic, will procure that they [Catholics] be killed and persecuted." He further warned Ingoli that their champion, Ras Śəəəä Krəstos, would have no chance of taking over the throne because of his low birth and that Susənyos's death would usher in "very grave damage for the Jesuits and Catholics in general, who would have little chance under the new king [Fasilädäs]." Șägga Krəstos suggested that he could go to "Ethiopia by the Red Sea route, and land in a port called Massawa, because there are lords and princes friends of his, whom he hopes will help him arrive to the Ethiopian Empire."77 The assessment was sound: for the Jesuits, who had been on the defensive since the early 163os, the accession of Fasilädäs, an anti-Catholic emperor, would herald the end of their mission. By adumbrating their and Susənyos's likely demise, Șägga Krostos presented himself as a godsend, a deus ex machina who could save the Catholic day.

Ingoli was greatly impressed by his protégé's assessment: "from these grand thoughts your excellency [Antonio Barberini] can deduce that this youth was

73 Francesco Ingoli to Antonio Barberini [spring 1633], Rome, APF, SOCG 211, 158r.

74 Martínez d'Alós-Moner, Envoys of a Human God, 292-310.

75 Ingoli learned about Susenyos's declaration of religious freedom (June 1632) in spring 1634 while Șägga Krəstos was in Venice: Francesco Ingoli, "Dubbio intorno al Signore Etiope," undated, APF, SOCG 104, 178r.

76 The reference is to atege Wāld Śä́ala, whose stance towards the Jesuit is however unclear: Wāld Śä́ala in E.A. IV,1094-1095.

77 Francesco Ingoli to Antonio Barberini [spring 1633], Rome, APF, SOCG 211, 158rv. 
not a lowborn, hence it is opportune to reflect on his disposition." ${ }^{78} \mathrm{He}$ was also suspicious of Șägga Krəstos's expanding social circle, however, and suggested to move him to "some place outside [of Rome] belonging to the friars, so they can endear him in the way one can endear a nobleman" to stir him towards the Emir of Saida. The reasoning was elegantly pragmatic: "if he is not who he claims to be, his return will not matter much, but if he is, [...] well instructed, well treated, we can imagine he will support the Catholic religion, especially if accompanied by four good Franciscan fathers." ${ }^{79}$ However, Ingoli was underestimating his guest's determination to pursue his own interests.

Aware of his status and leverage, and growing increasingly skilled in the art of self-fashioning, Ṣagga Krəstos must have realized that "there is always more than one authority and more than one alien in existence." ${ }^{80}$ He never agreed to the rural retreat Ingoli had envisioned and instead stayed in Rome to continue his negotiations with multiple authorities. Weeks later, an increasingly frustrated Ingoli reported to his prefect that Ṣägga Krəstos "does not want to be handled by the Grand Duke or by any other European prince other than the Dutch." ${ }^{\prime 1}$ Little did Ingoli know that, as later events would show, Șägga Krəstos was hardly interested in placing himself under Protestant aegis, let alone returning to Ethiopia; instead, he was exploiting the option as leverage. Incapable of stopping Ṣägga Krəstos from pursing his own plans - ostensibly that of traveling to Venice to embark for the Netherlands - Ingoli opted to assign him a Franciscan escort.

\section{Northern Italy}

After a year in Rome, Șägga Krəstos left in the company of four Franciscans meant to accompany him to Ethiopia: Ignazio da Perugia, Paolo da Roma, Simone da Sezze, and Antonio da Virgoletta. The latter headed the party, under the impression that he would soon be appointed prefect of the impending mission and sail to Ethiopia. ${ }^{82}$ In Venice by December 1634 , the young missionaries, eager to serve God among infidels, became increasingly frustrated with the many delays and setbacks they experienced: their correspondence

78 Francesco Ingoli to Antonio Barberini [spring 1633], Rome, APF, SOCG 211, 158rv.

79 Francesco Ingoli to Antonio Barberini [spring 1633], Rome, APF, SOCG 211, $158 \mathrm{v}$.

8o Greenblatt, Renaissance Self-Fashioning, 9 .

81 Francesco Ingoli to Antonio Barberini [fall 1633], Rome, APF, SOCG 211, 164r.

82 On the friars: Teodosio Somigli, Etiopia Francescana nei documenti dei secoliXVII e XVIII, vol. 1 (Florence, 1928). 
betrays growing anxiety and distrust towards Ṣägga Krəstos's inconclusive negotiations.

Father Antonio unsuccessfully petitioned the Venetian senate to sail to Ethiopia under Venetian auspices, on English or Dutch ships, via Hormuz: as Ingoli expected, the savvy leaders of the Republic had no intention of antagonizing the Ottomans over the fate of a pretender without credentials. ${ }^{83}$ In the meantime, the resident Polish ambassador reportedly cautioned Șägga Krəstos against traveling through the Caucasus because of ongoing conflicts, leading him to make inquiries with "Persians sent by the King," also to no avail. ${ }^{84}$ By June he was reportedly pursuing the English-Dutch option again, which, absent Venetian patronage, greatly worried the friars as it would entail "trusting himself in the hands of heretics." 85 Was Șägga Krəstos to be stopped, and if not, were the Franciscans to follow him among Protestants? Given that the last news from Ethiopia showed that "the schismatic faction is prevailing," Ingoli reasoned, he should not be stopped because "Catholic and very learned [... he] will not fall for Dutch and English dogmas"; instead he could "succeed the current emperor [Susənyos] who is $70 .{ }^{86}$ Ingoli, seemingly confident about Șägga Krəstos's faith, stayed the course, but by late June, Șägga Krəstos's plans changed again: cross the Po Valley, reach Marseille, and sail to Paris. ${ }^{87}$ His changes of mind and procrastinations frustrated the friars. Even the most supportive among them, Father Antonio, was puzzled at Șägga Krəstos's refusal to consider the promising Persian option.

After more than six months in Venice, the party left for Mantua, reaching the city in late June. A local chronicle relates that "the son of the Ethiopian Emperor, a prince about 22 years of age, tall with large and dark eyes, of saturnine temperament and few words" was housed at the court where "the Duke [Carlo I Gonzaga, 1627-1637] had him served magnificently." ${ }^{88}$ According to Father Simone, Șägga Krəstos had reached the city sick, and the Duke "had

83 Antonio da Virgoletta to Francesco Ingoli, 29 April 1634, Paris, APF, Socg 10, 228r. On Venetian-Ethiopian relations and Venice's caution: Salvadore, The African Prester John, 21-35; Paolo da Roma to unknown, 3 June 1634, Venice, APF, SOCG 104, 168r.

84 Shah Safi (1629-1642). Father Antonio related this to his brother, months later: Antonio da Virgoletta to Mattia della Porta, 2 September 1634, Turin, APF, SOCG 9, 124r.

85 Paolo da Roma to unknown, 3 June 1634, Venice, APF, SOCG 104, 168r.

86 Ingoli "Dubbio interno al Signore Etiope," undated, APF, SOCG 104, 178r. Susənyos was in fact already dead.

87 Antonio da Virgoletta to Francesco Ingoli, 28 June 1634, Venice, APF, SOCG 10, 229 r.

88 Federigo Amadei, Cronaca Universale della città di Mantova, Biblioteca Comunale Teresiana (Mantova), Ms. 106o, 351v-152r. Likewise, another local chronicler recorded the transit along the same lines: Giovanni Mambrino, Dell'historia di Mantova [...], Archivio di Stato di Mantova, Documenti patri D'Arco, n. 8o, 1044. 
him treated with the utmost diligence, as if he had been his own son, and ordered the ministers to serve him as a son, and he [the Duke] went to visit him and stayed with him a long time [...] high-ranking people are enslaved to him as soon as they meet him and aspire to serve him [emphasis added]."89 Further, once his guest had been received, the Duke "donated him 200 scudi, and had him accompanied by carriage until here in Parma, where also this Duke [Odoardo Farnese, 1612-1646] is treating him very well." 90

Curiosity for the exotic, courtly display of generosity, and compassion for an ill youth were likely among the reasons behind the generous support. In the early 1600 s, the average personal annual income was thirty-seven ducats in Venice and ten in the city's hinterland: Șägga Krəstos proved to be a charming guest provided for in splendid ways. ${ }^{91}$ Not everyone was impressed, however: Father Paolo questioned Șägga Krəstos's motives and intentions to entrust himself in the hands of Protestants and left. ${ }^{92}$ By mid-July, the party reached Piacenza, where Șägga Krəstos weathered a new bout of fever. After six weeks in the city, the party departed, seemingly for Genoa to embark on a Dutch or English ship, but by late August the four were in Turin instead. ${ }^{93}$

The papal nuncio to Savoy, Alessandro Castracani, noted Ṣägga Krəstos's arrival and his lingering illness in his periodic communications with Rome. ${ }^{94}$ Presumably at Ingoli's behest, he cautioned the young Ethiopian against the English option and tried to persuade him to head to Iberia. ${ }^{95}$ Having recently been appointed Collector of Portugal, thereby becoming supervisor of all Portuguese overseas missions, Castracani was ideally positioned to extol the merits of Iberian patronage, but he was only half successful. Șägga Krəstos abandoned the British-Dutch option but remained unconvinced about the Iberian, demanding that the king of Spain and Portugal had "promised by swearing to protect him and assist him, and that in exchange he would give the king a dock and a port next to the Empire" [emphasis added] ${ }^{96}$ Castracani

89 Simone da Sezze to Francesco Ingoli, 30 June 1634, Mantua, APF, socg 9, 313r.

90 Ignatio da Perugia to Francesco Ingoli, 12 July 1634, APF, SOCG 104, 179r.

91 Fernand Braudel, Civilization and Capitalism: 15th-18th Century, vol. 2 (Berkeley, CA, 1992), 218. This is also confirmed in Ṣagga Krəstos's letter to the Duke: Ṣägga Krəstos to Carlo I, 8 July 1634, Parma, Archivio di Stato di Mantova, Autografi Anni 1439-1876, Busta 1, $19 r$.

92 Paolo da Roma to Francesco Ingoli, 8 July 1634, Mantua, APF, SOCG 104, 177r.

93 Antonio da Virgoletta to Francesco Ingoli, 31 August 1634, Piacenza, APF, socg 9, 256r. The date, which appears added later, is incorrect because by the end of August the party was already in Turin (see next note).

94 Alessandro Castracani to Francesco Barberini, 26 August 1634, Turin, BAV, Barb. lat. 7168,12or.

95 Alessandro Castracani to Francesco Ingoli, 28 October 1634, Turin, BAV, Barb. lat. 9, 126r.

96 Alessandro Castracani to Francesco Ingoli, 2 December 1634, Turin, BAV, Barb. lat. 9, 114r. 
noted Ṣagga Krəstos's impertinence in his report to Barberini: the two prelates must have smiled at the youth's audacity of making demands of King Philip IV of Habsburg, whose empire stretched from the Americas to the Philippines, in exchange for the unsubstantiated promise of a port. Sägga Krəstos was too shrewd to be unaware of his own insolence: he probably deployed it to obliquely reject an unattractive option.

The friars were spent: they had lived with Șägga Krəstos's many delays and changes of heart and even agreed to consign themselves into the hands of heretics. More than a year into their journey, however, and nowhere closer to Ethiopia, they had exhausted their patience. One of them, most likely Father Simone, shared his misgivings with the hosts, in particular with local clerics, who began questioning Sägga Krəstos's hesitation, lack of credentials, and faith. ${ }^{97}$ They accused him both of simulation - pretending to be the heir he was not - and dissimulation - pretending to be Catholic. ${ }^{98}$ In turn, Ṣägga Krəstos lamented to Cardinal Barberini that "in this city of Turin they [the friars] have done nothing but [are] trying to harm me ... saying that their superiors sent them by force as missionaries without a dime, and [using] other terms not for clerics," adding that "if these friars will go among heretics, they will not bring about anything but scandal for the Catholic Church." 99 In addition, probably coached by the new nuncio Fausto Caffarelli (1595-1651), an old acquaintance of his from his Roman days, Șägga Krəstos underwent confirmation to buttress his religious credentials - a repeat of his original act of religious self-fashioning in the Holy Land. ${ }^{100}$ On the evening of Sunday, April 1, 1635, in "the Cathedral, His Highness [Vittorio Amedeo I di Savoia, 1630-1637] acted as godfather to the great Prince of Ethiopia." ${ }^{101}$ Little did Ṣägga Krəstos know that three centuries later, two among the Duke's descendants would become, however briefly, Emperor and Viceroy of Ethiopia. ${ }^{102}$

97 Antonio da Virgoletta to Francesco Ingoli, 18 March 1635, Turin, APF, SOCG 135, 23r; Antonio da Virgoletta to Francesco Ingoli, 25 March 1635, Turin, APF, SOCG 135, 19 r.

98 On the distinction between simulation and dissimulation: Perez Zagorin, Ways of Lying (Cambridge, MA, 2014), 3.

99 Șägga Krəstos to Antonio Barberini, 6 May 1635, Turin, APF, SOCG 135, 11r.

100 Șägga Krəstos had met Fausto Caffarelli near Naples. The young archbishop, hailing from a powerful Roman family, was traveling to Rome to be appointed nuncio to Savoy. He befriended Șägga Krəstos and facilitated his unsanctioned wanderings throughout Rome by providing him with a carriage. Verniero, 293-294.

101 Fausto Caffarelli to Francesco Barberini, 1 April 1635, Turin, BAV, Barb. lat. 7169, 71r.

102 As a result of the Second Italo-Ethiopian War (1935-1936), Ethiopia was declared part of the Italian Empire. King Vittorio Emanuele III (1900-1947) claimed the crown of Emperor of Ethiopia, and his first cousin, Prince Amedeo di Savoia, became Ethiopia's Viceroy of Ethiopia until he surrendered to British forces in 1942: "Italian War 1935-36," in 
The ritual seemingly placated local critics but failed to assuage the friars, who despite Caffarelli's mediation asked to be relieved. ${ }^{103}$ Father Simone left for Rome, and Father Antonio and Father Ignazio opted to stay in Turin to prepare an independent mission to Ethiopia or somewhere else in Africa. ${ }^{104}$ Șägga Krəstos left for Paris by himself, with the generous support of his Savoyard godfather who gave him "20o scudi after having spent twenty for him per day."105

\section{Paris}

By mid-June, Șägga Krəstos was in Paris with Father Antonio and Father Ignazio: the two had caught up with him in Lyon, after either changing their minds or being instructed to do so. The sojourn unfolded along familiar lines: the friars soon grew restless, while Șägga Krəstos worked to establish himself among the city's elites. Within weeks, Father Ignazio wrote to Ingoli that, "considering our two-year experience, we got to know him well and he does not want to return to Ethiopia."106 Antonio confirmed that he "wants to stay in Paris for many years, and after that he wants to go to his homeland to fight his enemies [emphasis added]." 107 Their views dovetail with the view of an additional informant: Tommaso Campanella (1568-1639), the controversial Dominican theologian best known for his early Utopian work The City of the Sun (1602), who was living in exile in Paris. ${ }^{108}$

Campanella, who had first met Ṣägga Krəstos in Rome, told Ingoli that he was intelligent, knew almost the entire Bible by heart, and that any accusations of heresy against him were groundless. ${ }^{109}$ Like many, the philosopher had been charmed. He advised supporting Father Antonio's plan to travel to Ethiopia independently to "find out the truth about the prince and ... open him the way for when the Most Christian King will send him with a galleon."

Encyclopaedia Aethiopica [henceforth EA], vol. 3, 228-234; and “Africa Orientale Italiana," in EA, vol. 1, 129-134.

103 Fausto Caffarelli to Francesco Ingoli, 27 August 1635, Turin, APF, SOCG 135, 25 rv.

104 Ignazio da Perugia to Francesco Ingoli, 31 July 1635, Paris, APF, SOCG 135, 3or; Antonio da Virgoletta to Francesco Ingoli, 28 May 1635, Lyon, APF, SOCG 135, 29 r.

105 Minutes of a letter by Fausto Caffarelli, 2 July 1635, Turin, APF, SOCG 135, 28r.

106 Ignazio da Perugia to Francesco Ingoli, 31 July 1635, Paris, APF, SOCG 135, 3 or.

107 Antonio da Virgoletta to Francesco Ingoli, 28 August 1635, Paris, APF, SOCG 135, 12r.

108 Luigi Firpo, "Campanella, Tommaso," in Dizionario Biografico degli Italiani, 17 (1974), http://www.treccani.it/enciclopedia/tommaso-campanella_(Dizionario-Biografico).

109 Tommaso Campanella to Francesco Ingoli, 11 September 1635, Paris, in Luigi Amabile, Fra Tommaso Campanella ne' castelli di Napoli, in Roma ed in Parigi, vol. 2 (Naples, 1887), 284. 
Campanella also believed that Ṣagga Krəstos had no intention of traveling to Ethiopia, at least not until an exploratory mission had ascertained the region's condition. He suggested keeping him in Paris, where he was already "much caressed by the Cardinal Duke [Richelieu] and the King."110

Did Șägga Krəstos want to return at all? Campanella seemed satisfied with the two-step plan, but the friars and the nuncio, Giorgio Bolognetti (15951680), were more skeptical. They reported that the youth was running out of funds and that the Franciscans had evicted him from their hospice, as he could no longer afford the room and service they had been providing him. ${ }^{111}$ In a unique letter to Cardinal Richelieu, Șägga Krəstos illustrated his predicament and gave away his intentions:

You know I am waiting for your rescue; perhaps you have not been advised that I have been reduced to a hermit, and that my host decided to dismiss me for lack of payment. Were I in a condition to be able to work to sustain myself, instead of hoping in the courtesy I need from the King and your excellency, I would force myself to do so. ${ }^{112}$

He asked for support not to leave but to stay. His melodramatic plea worked well: Louis XIII awarded him a whopping 8oo scudi annual pension for his maintenance. ${ }^{113}$ By comparison, in Tuscany, Emir Fakhr al-Din had received an annual subsidy of 2000 scudi, a paltry one considering it was meant for his entire clan of "twelve women with five or six children, seven or eight men and their suites of slaves, about 300 in all."114 By all counts, Ṣagga Krəstos was doing very well.

In the meantime, Ingoli had learned of Emperor Susənyos's death and of Emperor Fasilädäs's expulsion of the Jesuits from court, the restoration of Ethiopian faith, and persecution of Catholics. He advised his prefect to send Şägga Krəstos to Ethiopia with French Capuchins and redirect Father Antonio to Kongo, where he could fulfill his missionary call: in March 1636, Father Antonio

\footnotetext{
110 Tommaso Campanella to Francesco Ingoli, 11 September 1635, Paris, in Amabile, Fra Tommaso Campanella, 284.

111 Antonio Virgoletta to Francesco Ingoli, 21 October 1635, Paris, APF, SOCG 135, 46r; Antonio da Virgoletta to Francesco Ingoli, 7 December 1635, Paris, APF, SOCG 135, 23r.

112 Șägga Krəstos to Cardinal Richelieu, 5 December 1635, Paris, Archives du Ministère des Affaire Étrangères, Indes Orientales, Tome 2, 1, 6rv.

113 Giorgio Bolognetti to Francesco Ingoli, 7 March 1636, Paris, APF, SOCG 135, 35rv.

114 Quoted in Gorton, Renaissance Emir, 77.
} 
left for Rome, parting ways with Ṣägga Krəstos for good. ${ }^{115}$ In Paris, without a Franciscan escort and with a substantial pension in his pocket, Șägga Krəstos repositioned himself as a client of the Most Christian King and his shrewd First Minister. Expectedly, the flow of communication to Propaganda Fide dried up: over a year later, on October 6, 1637 a seemingly bored Campanella noted that "the prince of Ethiopia is here as usual, nec proficit nec deficit." ${ }^{\text {"16 }}$ Little did he know that excitement was around the corner.

In early November 1637, Șägga Krəstos was apprehended in the outskirts of Paris, "taken to prison, accused of trying to poison a councilman to marry his wife, with whom he had a relationship."117 He had exchanged marriage vows with one Magdalene Alamant, wife of François Saulnier, a Parisian notable, and tried to elope with her. ${ }^{118}$ "But the worst is what was found in the papers of these two lovers" - the French scholar Gabriel Naudé told his Roman acquaintance Cassiano dal Pozzo - "many letters of a certain Nun Catarina Angelica Masini, from the Monastery of Cosimato in Rome."119 The letters do not appear to have survived, but in his vows to Magdalene, Șägga Krəstos had in fact sworn to "abandon and renounce any love, passion and affection that I had in the past and I could presently still have, for Madame Catharina Angelica Massima, resident in Rome in the Convent of Saint Cosme."120 Evidently apart from socializing with powerful individuals, Șägga Krəstos had also found time to cultivate

115 Francesco Ingoli, "Parere del Secretario," 17 January 1636, Rome, APF SOCG 135, 9r. In 1637, Father Antonio was finally dispatched to Ethiopia, but he would never travel beyond Massawa, on the coast of present-day Eritrea. Following the restoration of the Ethiopian Church and the expulsion of the Jesuits, Emperor Fasilädäs negotiated Ottoman support to prevent the entry of more missionaries. At his behest, Massawa's pasha had Antonio deported to Sawākin, in present day Sudan, where the friar died of natural causes in 1641. The Ottoman had turned today's Eritrean coast into Habes Eyaleti in the mid-sixteenth century: "Habes," in EA, vol. 2, 950-952; Matteo Salvadore, "Muslim Partners, Catholic Foes: The Selective Isolation of Gondärine Ethiopia," Northeast African Studies 12, no. 1 (2012): 57-59.

116 Tommaso Campanella to Francesco Ingoli, 6 October 1637, Paris, in Tommaso Campanella, Lettere, a cura di Vincenzo Spampanato, vol. 103 (Bari, 1927), 384-385.

117 Giorgio Bolognetti to Francesco Barberini, 17 November 1637, Paris, Archivio Segreto Vaticano [ASv], Segr. Stato, Francia, b.84, fol. 154v.

118 Gédéon Tallemant des Réaux, Les historiettes de Tallemant des Réaux, ed. Paulin Paris, vol. 4 (Paris, 1863), 71.

119 Gabriel Naudé to Cassiano dal Pozzo, 8 February 1638, Paris, Biblioteca dell'Accademia Nazionale dei Lincei e Corsiniana, Rome, Ms. Cassiano dal Pozzo xxxviıI (35), 66v.

120 Valentin Conrart, "Promesse de mariage de Zagachrist et de Madame Saulnier en l'an 1637," Recueil de pièces historiques, Tome II (1629-1638), Bibliothèque nationale de France, Ms. 3447, 216r-217r. 
an intimate relationship with a nun in the Convent of San Cosimato, minutes away from his residence in Trastevere.

Accused of adultery and possibly of attempted murderer, Șägga Krəstos was detained for weeks at Paris's Grand Châtelet, where Isaac de Laffemas (1587-1657), lieutenant general for civil and criminal affairs, attempted to interrogate him. Reportedly, Ṣägga Krəstos was extremely defiant. In an extreme act of self-fashioning, Șägga Krəstos told his interrogators that "if I am not acting like a prisoner, ... this is because of my status that cannot be imprisoned under any circumstances," and he repeatedly refused to acknowledge the authority of his interlocutors, claiming that he "was not born to obey, but rather to command." "121 These were Șägga Krəstos's last reported words. On April 22 "at 10 in the evening in Ruel, the Prince of Ethiopia called Zaga Christos died of pleurisy at age 22. He had sojourned in France for three years and he was always assisted by the people of His Eminence [Richelieu]."122

The obituaries that appeared in multiple French and Italian bulletins are silent on the circumstances of his arrest and the events leading him to Cardinal Richelieu's residence in Ruel: it can be surmised that the latter intervened on his behalf either to avoid scandal, out of compassion for his health conditions, or because of diplomatic considerations. At any rate, his six-year-long journey or, to borrow a well-suited rendition of self-fashioning, his "endless costume ball from which one might be summarily expelled" was over. ${ }^{123}$

\section{Afterlife}

Cross-checking the Narratione and the Brevissima against available Ethiopian and European sources, along with his behavior across Italy and France, leaves little doubt that Șägga Krəstos was an impostor. His decisions and indecision betray a lack of interest in repatriation, as some of his Franciscan companions had realized early in their journey. Șägga Krəstos lied about his paternity, but did he also lie about his nobility? His refined manners and, despite the chronological inconsistencies, his recollection of Ethiopia's dynastic history suggest that he was a highborn, most likely the son of a noble. Alternatively, as suggested in the anonymous report, he could have been a monk looking for handouts

121 "Reply of His Highness the Prince of Ethiopia," Bibliothèque nationale de France, Rés Z. Thoisy 48: Recueils historiques $1625^{-1638}$, fols. $35^{2 r}-35^{6 \mathrm{v}}$.

122 Theophraste Renaudot, Recueil des Gazettes Nouvelles Relations Extraordinaires et autres recits des choses avenues toute l'annee 1638 (Paris, 1639), 196. Another bulletin had him die at age twenty-four: Renaudot, Vingt-Deuxième Tome, 254.

123 Sanjay Subrahmanyam, Three Ways to Be Alien (Waltham, 2011), 5. 
in collusion with other rogues posing as servants. ${ }^{124} \mathrm{~A}$ shrewd educated monk could have posed as a royal heir: Ethiopian monasteries, as repositories of religious and secular knowledge, were ideal locales to become conversant with both Ethiopian history and court intrigue. Among Ṣägga Krəstos's possessions were at least two religious manuscripts that found their way to the Bibliothèque Nationale de France and suggest access to a monastery, a church, or a noble family's library.125 One can only speculate on Ṣägga Krəstos's noble or monastic upbringing, but he was no lay commoner and was undoubtedly Ethiopian.

For an impostor, Șägga Krəstos fared very well, thanks to uncanny selffashioning and an ideal context: Jesuit-Franciscan competition, Ingoli and Propaganda Fide's aspirations, and, later, Susənyos's abdication followed by Jesuit expulsion all contributed to creating an ideal milieu for his act. Furthermore, the lingering discourse on Ethiopia as the kingdom of Prester John afforded Șägga Krəstos additional discursive capital. ${ }^{126}$ His interlocutors mostly refrained from either confuting or endorsing his claim and positioned themselves in a gray area, but they mostly supported him quite generously. Some saw him as a geopolitical asset, others as an exotic guest enhancing their standing - someone who could adorn their court. ${ }^{127}$ Many seem to have sincerely liked this exotic, charming young man and to have fallen in love with him - some quite literally.

In some ways, Ṣägga Krəstos's story is also reminiscent of 'Ali bin Yusuf 'Adil Khan's: claimant to the Sultante of Bijapur, he lived in Portuguese Goa for more than two decades as the Portuguese tried, unsuccessfully, to utilize him as part of their expansion in the Deccan. Like Șägga Krəstos, Meale - as the Portuguese called him - was mostly perceived as a valuable asset by his hosts. However, despite the certainty of his identity and royal claim - which placed him at an advantage compared to Ṣägga Krəstos - he remained a devout Muslim throughout his Goan sojourn, was never regarded as anything but an alien, and could never emancipate himself from his captivity - unlike his

\footnotetext{
124 Anonymous document, 1633, BAV, Barb. lat. 4605, 9ov.

125 Ethiopien 119 and Ethiopien 103, Bibliothèque nationale de France. See Hermann Zotenberg, Catalogue des Manuscrits Éthiopiens de La Bibliothèque Nationale, 1877, 97 and 141.

126 For example: "si pretende appartenergli di ragion l'Imperio del Preteianni," Alessandro Castracani to Francesco Ingoli, 2 December 1634, Turin, BAV, Barb. lat. 9, 114r; "Imperadore d'Ethiopia, da noi detto Pretegianni," in Bisaccioni, Seconda continuatione, 57.

127 The literature on the Africans and in general non-European presence at early modern European courts is vast. An excellent entry point is Paul H.D. Kaplan, "Isabella d'Este and Black African Women," in Lowe and Earle, Black Africans in Renaissance Europe, 125-154.
} 
children, who converted and assimilated into the city's elites. Șägga Krəstos, who possessed a fraction of Meale's political capital and resources, cunningly refashioned himself and enjoyed freedom and support throughout Europe. ${ }^{128}$

Ṣägga Krəstos's fortunes changed posthumously, when memories of his scandalous relationship and apprehension were reframed through racialized categories, turning him into a farcical epitome of uncontrolled African lust and duplicitous behavior that would entertain the French reading public for centuries. He was described as a "wonderful negro" who "should be crowned by the hand of Venus/who lubricated the famous cock of this prince/whose body was nothing but a spermatic vessel."129 His reputation also gained him references in French literature: the figure of the "Ethiopian Prince" appeared in plays such as Les Visionnaires (1639) by Jean Desmarets (1595-1676) and in a plagiarized version of Moliere's The Imaginary Cuckold (1662). ${ }^{130}$ Jean-Baptiste de Rocoles included a much-revised version of Șägga Krəstos's statement in Les Imposteurs Insignes, a fundamental text for the emergence of the impostor as a literary figure. ${ }^{131}$ Intriguingly, in the same decades, France witnessed a substantial evolution of the discourse on difference as a result of growing interest in the overseas and the African coast in particular: in 1655, Isaac de la Peyrere became an early proponent of polygenism; and in 1688, Francois Bernier produced his groundbreaking racial classification of humankind..$^{132}$

Albeit in a less extreme form, Șägga Krəstos's posthumous fate is reminiscent of two early modern Afro-Iberian freedmen: Juan Latino (1518-1596), who became professor of Latin at the Colegio Real in post-Reconquista Granada and married into the city's elites; and the acclaimed painter Juan de Pareja (16o6-1670). Unlike Sägga Krəstos, the two were of diasporic slave birth, were

128 Subrahmanyam, Three Ways to Be Alien, 23-72.

129 Poeme su Zaga Christ, roi d'Ethiopie, Bibliothèque nationale de France, Ms. 4127, 88ov881 . The undated and anonymous poem was printed, in a revised edition, in Anonymous, Poesies gaillardes et heroiques de ce temps, augmentées du poëme de Zaga-Christ, ou la mort du Roy d'Ethiopie, (n.d.) and appears to be the new edition of a previous collection that did not include the poem, L'Elite des poesies heroiques et gaillardes de ce temps, (1674).

130 Jean Desmarets, Les visionnaires, 2nd ed. (Paris, 1639), 17. Desmarets's play was first staged in 1637. Francois Doneau, La Cocue Imaginaire. Comédie (Paris, 1662), 6. On the latter's history: Georges Mongrédien, "Le Cocu Imaginaire' et 'La Cocuë Imaginaire," Revue d'Histoire Littéraire de La France 72, no. 5/6 (1972): 1024-1034.

131 Jean-Baptiste de Rocoles, Les Impostures Insignes (Paris, 1679); Davis, Remaking Impostors, 12; Eliav-Feldon, Renaissance Impostors, 14; Groebner, Who Are You? 216-219.

132 Siep Stuurman, "François Bernier and the Invention of Racial Classification," History Workshop Journal 50 (2000): 1-21. On the correlation between the emergence of racial categories in France and French exploration: William Benjamin Cohen, The French Encounter with Africans: White Response to Blacks, 1530-1880 (Bloomington, IN, 2003), $1-34$. 
emancipated because of their skills, and possessed neither political capital nor ambition. However, their posthumous trajectories converged: highly esteemed in life, in death they were ridiculed and racialized. Latino became caricatured as "El Negro Juan" in a late sixteenth-century play and as an illiterate black African in Cervantes's Don Quixote. ${ }^{133}$ Likewise, De Pareja's biographers turned the painter into a trickster. ${ }^{134}$ As Ruth Iyob aptly put it, the two Juans were victims of a posthumous "discursive assassination" - as was Șägga Krəstos. ${ }^{135}$

If their discursive fate can be understood as a function of the hardening of racial categories that survived well into the twentieth century, the diminution of Șägga Krəstos is also the function of archival neglect and questionable interpretative paradigms. A case in point is a 1985 study that turned Șägga Krəstos into a discursive artifact: "anything Europe wanted to make of [him] like soft wax with no character of its own," a "creature of French discourse," "a mythical foreigner presented as fully present and real [emphasis added]," who was "never more bizarre than when [he was] fully domesticated."136 While the posthumous denigration of Șägga Krəstos warrants some of these conclusions, reading his story as one of marginality and domestication seems a contrived attempt to fit a story of African assertion into the confines of postcolonial categories that confound rather than clarify the historical record.

Șägga Krəstos was an independent agent whose autobiographical statement, conversion, and confirmation were shrewd acts of self-fashioning that defined his trajectory from the streets of Cairo to Cardinal Richelieu's residence. It is likely that Ṣägga Krəstos's interlocutors harbored misgivings about his Africaness, yet none of the sources I consulted refer to it, which would suggest that racial or color prejudice was not part of an educated discourse among his acquaintances. None of Ṣägga Krəstos's interlocutors, not even his most bitter detractors, dwelled on it. His staunchest critic, Father Simone, criticized him vehemently, wrote choleric letters to Ingoli, accused him of heresy, yet in his correspondence one cannot find any trace of racial denigration. Detractors attacked Șägga Krəstos's royal claim, some questioned his faith, but none

133 Elizabeth R. Wright, The Epic of Juan Latino:Dilemmas of Race and Religion in Renaissance Spain (Toronto, 2016), 178-179.

134 Carmen Fracchia, "Metamorphosis of the Self in Early Modern Spain: Slave Portraiture and the Case of Juan de Pareja," in Slave Portraiture in the Atlantic World, eds. Agnes Lugo-Ortiz and Angela Rosenthal (Cambridge, 2013), 146-169.

135 Ruth Iyob, Globally Black: the making of African Diasporas in the Mediterranean, the Red Sea, the Indian Ocean, and the Caribbean Atlantic. forthcoming.

${ }_{136}$ Miller, Blank Darkness, 36-39. Miller chiefly consulted Giffre de Rechac, Les estranges evenemens dv voyage de Son Altesse, and Roger, La Terre Sainte, and read them as European texts. 


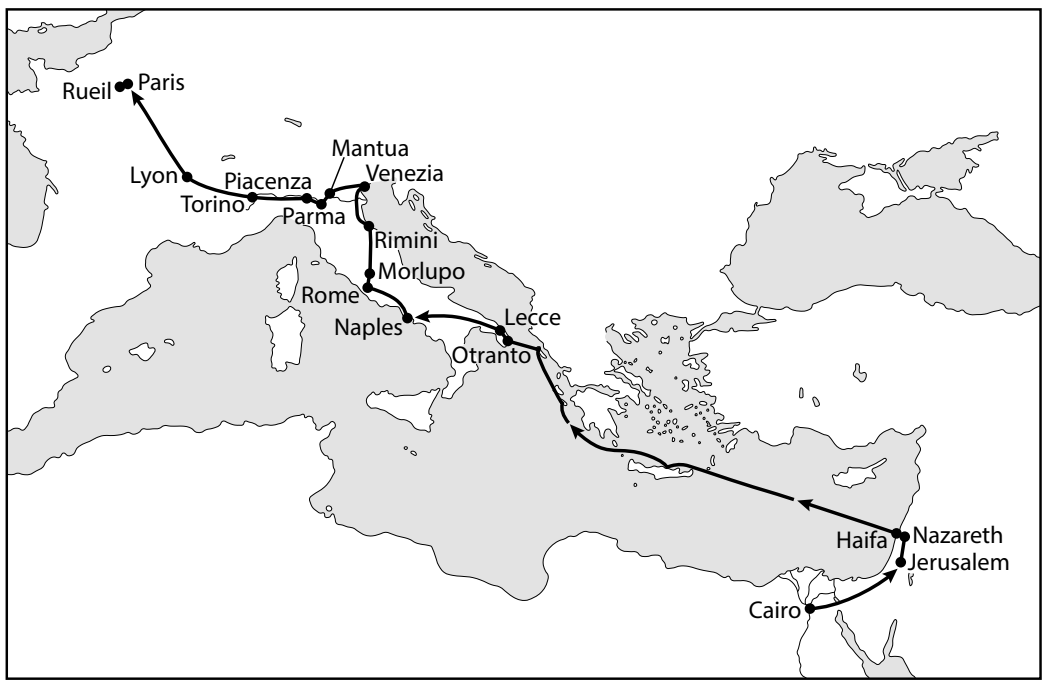

FIGURE 1 Ṣägga Krəstos's journey in the Middle East and Europe, 1632-1638. COX CARTOGRAPHIC LIMITED

disparaged or even discussed his Africaness, while the only references to his appearance are of a purely esthetic nature and all laudatory. Sägga Krəstos's case dovetails with that of Alessandro de' Medici (1531-1537), the Duke of Florence who was of part-African ancestry. A polarizing figure, his contemporary and posthumous detractors reviled him for his despotism and his low and illegitimate birth, but it was not until the eighteenth century that he became the subject of racist commentary. ${ }^{137}$

Şägga Krəstos's experience supports Joaneath Spicer's contention that "for reasons that are not entirely clear," in the early seventeenth century, multiple events in Europe "signal[ed] a new level of acceptance and status for Africans in Europe," and his legacy seems to confirm that "while these events may appear to presage a new era of normalization, with the perspective of time they look more like markers of the end of an era."138 The European perception of Africans, in particular of elite Africans, remained mixed, but undoubtedly it worsened along with the emergence of the Atlantic slave trade that went hand

137 Catherine Fletcher, The Black Prince of Florence: The Life of Alessandro de' Medici (New York, 2017), 251-26o; John K. Brackett, "Race and Rulership: Alessandro de' Medici, First Medici Duke of Florence, 1529-1537," in Lowe and Earle, Black Africans in Renaissance Europe, 303-304.

138 Spicer et al., Revealing the African Presence, 10. 
in hand with new paradigms of difference. Stories such as Șägga Krəstos's offer vistas on the complexity of the idea of race in early modern Europe and on the fluid interplay between color, status, and faith. As for Șägga Krəstos, race defined him in death, but not in life.

\section{Acknowledgements}

I would like to express my gratitude to James De Lorenzi and the two anonymous reviewers for their precious comments, Ruth lyob for prodding me to work on Ṣägga Krəstos for almost a decade, and Gianfranco Armando for his priceless advice on how to access archival material in Rome and elsewhere. At American University of Sharjah, I am particularly grateful to Chris Furno, Kathleen Furr, Madhav Das, and Vernon Pedersen. This research was supported by American University of Sharjah's Faculty Research Grant 19-S-S124. Free access is provided by American University of Sharjah's Open Access Grant OAP-CAS-084.

The views and opinions expressed in this article are those of the authors and do not necessarily reflect the official policy or position of American University of Sharjah. 